Article

\title{
Dual Battery Storage System: An Optimized Strategy for the Utilization of Renewable Photovoltaic Energy in the United Kingdom
}

\author{
Sarvar Hussain Nengroo ${ }^{1}{ }^{(D)}$, Muhammad Ahmad Kamran ${ }^{2}$, Muhammad Umair Ali ${ }^{1}$ (D), \\ Do-Hyun Kim ${ }^{1}$, Min-Soo Kim ${ }^{1}$, Altaf Hussain ${ }^{1}$ and Hee Jee Kim ${ }^{1, *}$ \\ 1 Department of Electrical Engineering, Pusan National University, Busandaehak-ro 63 Beon-gil 2, \\ Busan 46241, Korea; ssarvarhussain@gmail.com (S.H.N.); umairali.m99@gmail.com (M.U.A.); \\ kdh8486@naver.com (D.-H.K.); rlaalstn5@naver.com (M.-S.K.); ahussain1982@outlook.com (A.H.) \\ 2 Department of Cogno-Mechatronics Engineering, Pusan National University, Busandaehak-ro 63 Beon-gil 2, \\ Busan 46241, Korea; malik.pieas@gmail.com \\ * Correspondence: heeje@pusan.ac.kr; Tel.: +82-51-510-2364
}

Received: 15 August 2018; Accepted: 5 September 2018; Published: 7 September 2018

check for updates

\begin{abstract}
The increasing world human population has given rise to the current energy crisis and impending global warming. To meet the international environmental obligations, alternative technological advances have been made to harvest clean and renewable energy. The solar photovoltaics (PV) system is a relatively new concept of clean technology that can be employed as an autonomous power source for a range of off-grid applications. In this study, the dual battery storage system is coupled with a solar PV system and a low voltage grid, benefitting from the feed-in tariff (FIT) policy. The main outcomes of this study are: (I) A novel dual battery storage system for the optimal use of the PV system/energy is proposed; (II) The problem is formulated in the form of a mathematical model, and a cost function is devised for effective cost calculation; (III) An optimal cost analysis is presented for the effective use of PV energy; (IV) real-time data of a solar PV taken from the owner and the demand profile collected from the user is applied to the proposed approach, with United Kingdom (UK) tariff incentives. This system works in a loop by charging one system from the solar PV for one day, and discharging the other system. This model gives certainty that power is exported to the grid when the solar PV generates an excess amount; batteries are utilized during the peak hours, and power is purchased when the demand is not met by the batteries, or when the demand is higher than the generation. This study examined the economic knowledge of solar PV and battery storage systems by considering the FIT incentives.
\end{abstract}

Keywords: solar PV; feed-in tariff; battery storage system; demand profile

\section{Introduction}

\subsection{Energy Spread and Photovoltaic Technology/PV Energy and World Demand}

The increase in energy demand of developing countries is expected to be $65 \%$ by 2040 , indicating the emerging growth, prosperity, and developing economies of such areas [1]. In contrast, the energy demand in the world will increase to $35 \%$ with the increase in population. The Intergovernmental Panel on Climate Change (IPCC) shows that there has been a $40 \%, 150 \%$, and $20 \%$ increase in the concentrations of $\mathrm{CO}_{2}$, methane, and nitrous oxide, respectively, since pre-industrial times. As of 2015, two-thirds of global $\mathrm{CO}_{2}$ emissions are produced by the combustion of fuel, of which electricity generates $42 \%$. A considerable amount of anthropogenic greenhouse gases are released from the industrial zones (IZ) in different countries [2]. The detrimental effects of the unsustainable 
patterns of energy on social, health and environmental have been reported in [3-6]. According to [7], it is economically and technically feasible for renewable energy technologies (RETs) to be an alternate source for the present fossil fuel electricity infrastructure. The international energy agency (IEA) reported that the total installed capacity of the solar photovoltaics (PV) system in 2009 was $23 \mathrm{GW}$, which was ramped up by five times to $137 \mathrm{GW}$ in 2013, followed by an increase in capacity to $177 \mathrm{GW}$ in 2014. In 2016, the total global PV capacity was 303 GW, with 106 GW from European Union (EU), 77.4 GW from China, $42.8 \mathrm{GW}$ from Japan, and 40.9 GW from United States of America (USA) [8-11]. Of all the electricity produced in the world in 2016 from the renewable energy sources, which amounts to $24.5 \%$, the share of electricity from the PV is $1.5 \%$.

Advances in science and technology have provided several alternative means of producing energy on a sustainable level [12]. More attention is being paid towards PV technology, due to the decrease in the cost of PV modules, the long lifetime service, and the widely flexible applications [13,14]. The solar panels consist of a number of PV modules, which convert solar energy into electrical energy [15-17]. Different types of commonly used materials for PV modules nowadays include mainly monocrystalline, polycrystalline, and thin film technologies [18-20]. Amorphous silicon technology is thin film technology, which is low-cost and the most environmentally friendly, and its cost can be as low as to 0.06-0.09€/WP [21-23]. Solar PV technology can be considered as a backbone to shift our conventional energy sources to renewable and sustainable energy sources. The earth receives approximately $8 \times 10^{8} \mathrm{TW}$ hr energy from the sun each year, which equals to potentially around 8000 times more than the energy demand of the world [24]. PV energy and energy efficiency play a key role in global energy usage. A common example of this are solar street lighting systems. They reduce the load of the conventional energy system and are an important contributor to improve the energy efficiency. Pinter et al. [25], investigated the economic analysis of the installation of a solar PV system for street lighting purposes in a Hungarian village comprising of 900-1200 residents, and encouraged the deployment of the PV system.

\subsection{Energy Storage and Its Effective Utilization}

The sporadic nature of PV systems is the main drawback in matching intermittent energy production with load demand. To overcome this drawback, a hybrid system is utilized, which consists of solar PV and a dual energy storage system connected with load [26,27]. The installation of the hybrid PV and energy storage system is economically feasible to meet the consumer load demand, as more generating capacity uses solar and wind energy [28]. Nizetic et al. [29], investigated the design and performance of the hybrid system for different operating conditions, with the conclusion that the hybrid system can be a cost-effective solution for small- and medium-scale applications.

Energy storage system (ESS) refers to a transformation of electrical energy from a power network or renewable energy sources (RES) into a form that can be stored and utilized during peak hours, or when the generating source is unavailable. According to [30-33], large-scale energy storage technologies, such as thermal storage, pumped hydro storage, fuel cell storage, and supercapacitors, have financial and technical problems. Currently, the battery energy storage system (BESS) is the main focus, because of the ease of installation compared to other storage technologies [34]. The analysis of the study in [35] shows that the optimal management of hybrid PV and BESS connected with the utility grid resulted in reduced electricity costs. The study of the work in [36], developed a technology selection and operation (TSO) optimization model to find out the optimal selection of PV and battery systems in the commercial buildings. A multi-period mixed-integer linear program (MILP) model for the scheduling and planning of the PV-battery storage system to magnify the net cash flow was studied in $[37,38]$. The optimal flow of power management for the distributed energy resources with batteries to meet the consumer demand at low cost was presented in [39,40]. Pamparana et al. [41], developed a novel MILP model to optimize the operational costs of the induction of PV and battery energy storage with a semi-autogenous grinding mill. The advantages of the operational planning of 
nonconventional sources (wind power and PV) and the ESS has been discussed in [42,43]. The uptake of solar PV and BESS, and its profitability, is likely to eliminate dependence on power from the grid, and make independent homes or microgrids a possibility [44].

\subsection{Batteries and Feed-In-Tariff Incentives/Effective Cost, and the Impact of the PV System}

Nevertheless, most of the available literature in this area neglected the cost evaluation of tariff incentives. The operational planning of nonconventional sources (wind power and PV) and ESS has been discussed in. The use of batteries with PV systems to increase the self-consumption of electricity has expanded, particularly in Germany, Japan, Australia, and the USA [45,46]. Thus far, the batteries used in power system applications are deep cycle batteries (lithium-ion, lead-acid, flooded type, valve regulated type, sodium sulfur, metal ion, lithium-iron-phosphate, and flow batteries) having energy capacity in the range of 17 to $40 \mathrm{MWh}$ and efficiencies of approximately 70-80\% [47]. Lithium-ion batteries are used most frequently with the PV system [48]. Lithium-ion batteries are promising technology because of their high reliability, high energy density, low toxicity, high reliability, high efficiency, and long-life cycle [24,49]. The average cycle stability based on the depth of discharge (DOD) for lithium-ion is 6000 (80\% DOD) and for the olivine-type- $\mathrm{LiFePO}_{4}$, is 10,000 (100\% DOD) [28].

A feed-in tariff (FIT) is a scheme for the deployment of renewable energy technologies to support renewable energy producers by offering long-term purchase agreements [50-53]. According to [54], FIT policies have led to the establishment of more than 15,000 MW of PV power and more than 55,000 MW of wind power from 2000 to 2009 in the European Union (EU), and are responsible for approximately $75 \%$ and $45 \%$ of global PV and wind deployment, respectively. The USA was the first country that considered the Public Utility Regulatory Policies Act (PURPA) in 1978, which was based on the purchase of electricity generated from the Renewable Energy facilities at pre-established rates. In 1990, Germany's Electricity Feed-in Law implemented the Stromeinspeisungsgesetz (StrEG) policy to purchase electricity from the non-utility renewable energy generators at a fixed percentage of retail electricity [55].

The current need is to move away from non-replenishing energy sources, which pollute the environment by releasing large amounts of $\mathrm{CO}_{2}$ gases, towards the environmentally sustainable plants to mitigate the energy crisis, mainly in the power sector. The induction of batteries with a solar PV system serves as an alternate solution for the reduction of greenhouse gases, and to tackle peak shaving. Many different master plans have been developed to make use of PV energy with optimal results. Previous studies $[41,45]$ have examined the fruitful techno-economic analysis of integration of solar PV and battery storage systems as an independent power source to tackle the peak demand. In the proposed setup, two batteries were managed smartly by charging one system from the solar PV, while the other is used to meet the demand, and the process and charging and discharging is switched to make use of the system optimally. The capacity of the PV generating system is $3 \mathrm{~kW}$ and the capacity of each battery used in our proposed optimized model is $270 \mathrm{Ah}$. A mathematical model is devised for this system to determine the optimal cost for the proposed system.

\section{Material and Methods}

\subsection{Problem Formulation}

The increasing demand for energy has prompted several research groups to evaluate different renewable energy resources as a whole or as a share. Solar energy is one of the cheapest and easiest way to generate electricity to mitigate the energy crisis. On the other hand, the generation of electricity from solar energy is not continuous within a certain threshold, and has become a bottleneck depending upon the time of day, the thermal-environmental conditions, and the duration of light. Therefore, it can be regarded as a variable generator source throughout the year. Consequently, the generation capacity of a solar energy source sometimes leads or lags the demand, as shown in Figure 1. 

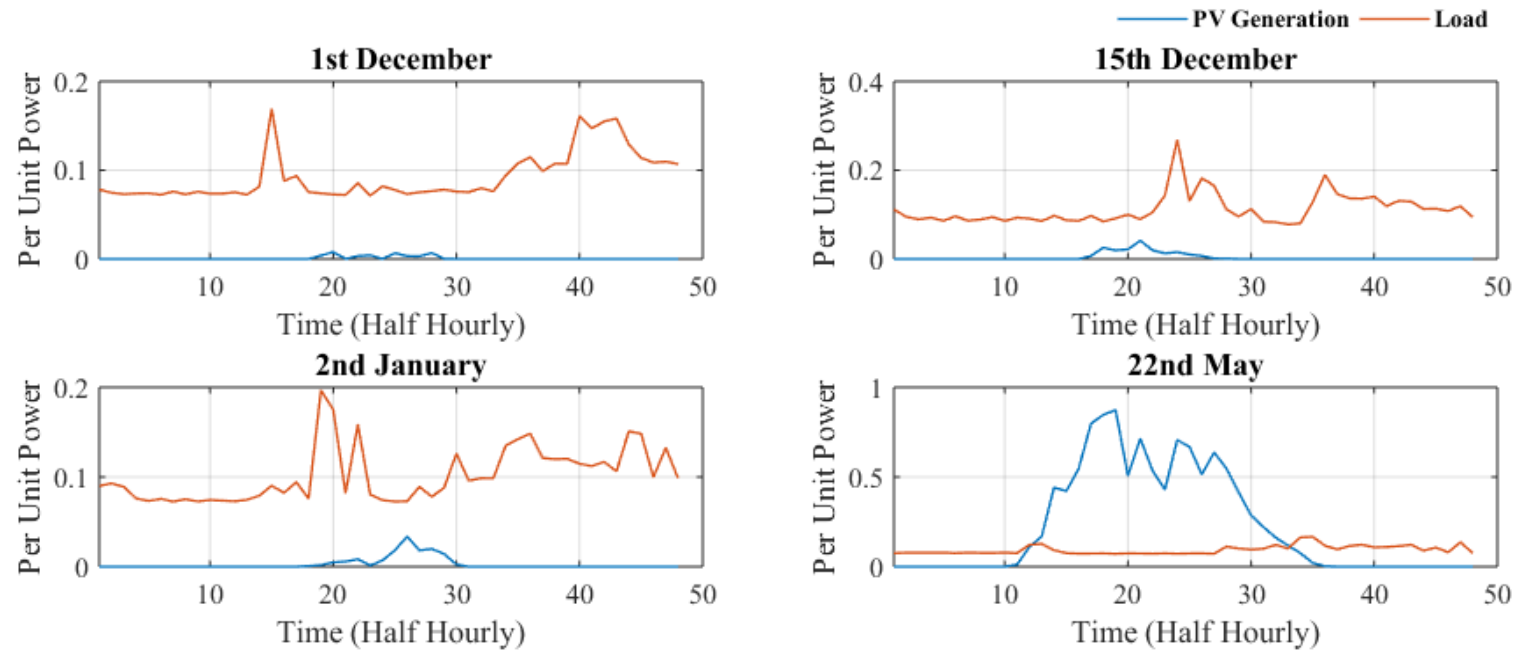

22nd May

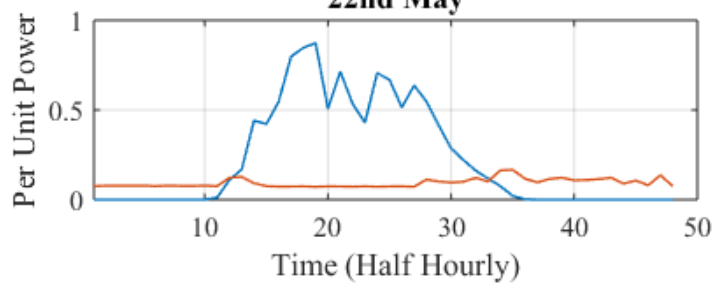

13th July
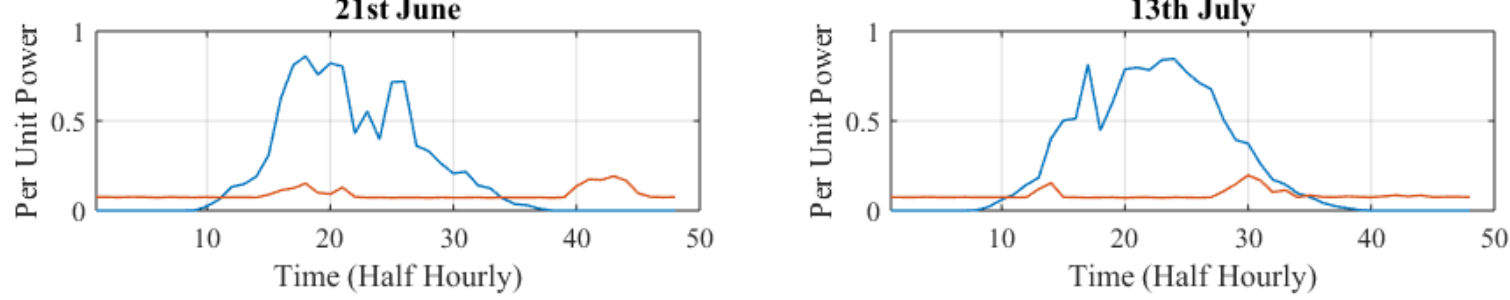

Figure 1. Per unit power profile of solar photovoltaics (PV) generation and the load of different days in a year.

The plots were taken for the different months of the year. In this figure, the blue lines show the generation of solar PV and the purple lines show the demand profile of the consumer. The plots in the top row from left to right were taken on 1 and 15 December, and the plot on the left of the second row was taken on 1 January, which indicates that solar PV generation lagged in demand, and power were provided by the grid also to fulfil the demand. The plots in the right of the second row were taken on $22 \mathrm{May}$, and the plots on the lower row were taken on 21 June, and on 13 July, indicating an excess of solar PV generation with respect to demand, which is exploited to charge batteries. The extra power was shifted to the grid utility when the charge in the batteries reached the maximum. This pattern showed that a solar plant can deliver power for an onsite load, it can export power when it exceeds the demand of certain area, and it can purchase electricity from the grid to supply a particular area during the time with less solar generation. Therefore, a mathematical function catering to this variability in the requirement of a solar energy unit is presented in Equation (1). In this study, a cost function $J_{1}$ is defined to represent the revenue generated by the solar panels:

$$
J_{1}=\max \sum_{d, t}\left[P_{g}(d, t) \times p_{g_{-} F I T}+P_{e}(d, t) \times p_{e_{-} F I T}-P_{i}(d, t) \times p_{i_{-} F I T}\right] \Delta \times t
$$

where $d$ represents the date of the year, $t$ represents the specific time of the day, $P_{g}$ is the generation power from the solar plant, $p_{g_{-} F I T}$ is the generation tariff, $P_{e}$ is the excess power, i.e., the difference of generation and demand, $p_{e_{-} F I T}$ is the export tariff, $P_{i}$ represents the power required by the grid to feed the load during unmet demand, and $p_{i \_F I T}$ is the import tariff rate.

This paper proposes the idea of utilizing two separate energy storage systems (batteries) $S_{1}$ and $\mathrm{S}_{2}$. The solar energy is stored in one storage unit, and the second one is used to deliver the power to a specific area for a specific time. In the second stage, the batteries are swapped; the first is used to supply power and the second is reserved for storage if excess power is generated. Thus, this system works in the loop, which is shown in Figure 2. 


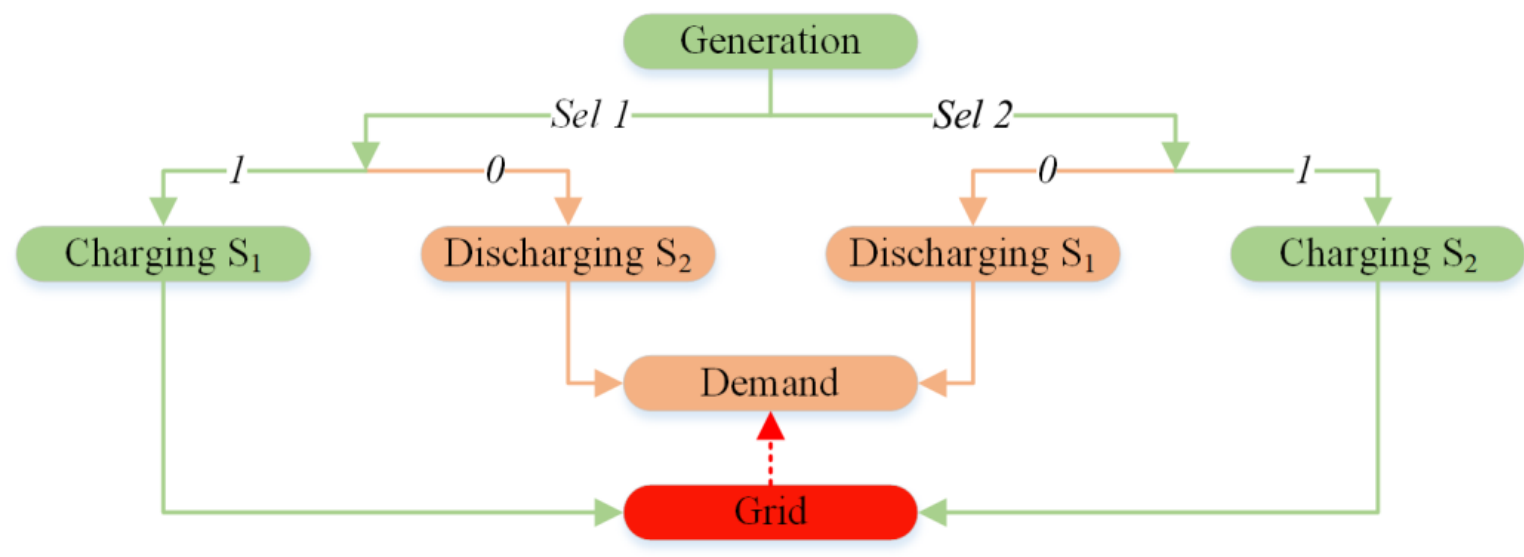

Figure 2. Schematic of charging and discharging for two energy centres, $S_{1}$ and $S_{2}$.

Overall, despite the increase in capital cost, the overall cost decreases.

The cost function, $J_{2}$, is defined as:

$$
J_{2}=\max \sum_{d, t}\left[\begin{array}{c}
P_{g}(d, t) \times p_{g_{-} F I T}+P_{1}^{\text {in }}(d, t) \times p_{\text {in } \_F I T}+P_{2}^{\text {in }}(d, t) \times p_{\text {in }} F I T+P_{1}^{\text {out }}(d, t) \times p_{o_{-} F I T} \\
+P_{2}^{\text {out }}(d, t) \times p_{o_{-} F I T}+P_{e}(d, t) \times p_{e_{-} F I T}-P_{i}(d, t) \times p_{i \_} F I T
\end{array}\right] \times \Delta t
$$

subjected to:

$$
\begin{array}{ll}
P_{i}(d, t) \geq 0, & \\
o \leq m n_{c}\left(s_{k}\right) \leq P_{k}^{\text {in }} & k=1,2, \\
o \leq P_{k}^{\text {out }} \leq m x_{c}\left(s_{k}\right) & k=1,2,
\end{array}
$$

where $P_{k}^{\text {in }}$ and $P_{k}^{\text {out }}$ represent the power that is used to store and to feed in, respectively, for the storage unit $k=1,2 ; m x_{c}\left(s_{k}\right)$ and $m n_{c}\left(s_{k}\right)$ represent the maximum and minimum storage capacities, respectively, and $P_{i}$ represents the power that is imported from the grid, $P_{e}$ represents the power excess power that is exported to the grid.

\subsection{Methodological Detail}

In the United Kingdom (UK), there are various means, such as reduced value-added tax (VAT), capital grants for householders, and schemes like Renewable Obligation (RO), and feed-in-tariff to embrace these microgeneration technologies [56]. This paper examines the deployment of batteries with the PV system under FIT incentives and time-varying electricity tariffs with the aim to reduce electricity bills. Figure 3 shows the power flows to the load from the utility grid, coupled with the PV and the energy storage system. The equipment and materials used for the flexible storage system include: PV modules, PV-inverters, a battery-inverter, a battery, a frame on the roof, cables, and outlets [28]. Solar PV modules consist of an assembly of solar PV cells, which convert the solar energy into direct current (DC) through the photovoltaic effect. The DC current was inverted by the power electronic inverter into alternating current (AC) to feed the load. The solar PV power was utilized onsite to provide power to the load. When there is excess power, it is prioritized by storing the power in the batteries first, until the batteries reach the maximum state of charge (SOC). The surplus power is then exported to the grid at the prescribed export tariff. The batteries are employed to backup to meet the demand, if the demand is not met by the solar system. When the SOC of the batteries falls below the prescribed limit, the power from the battery is curtailed and the power is imported from the grid at the described tariff. 


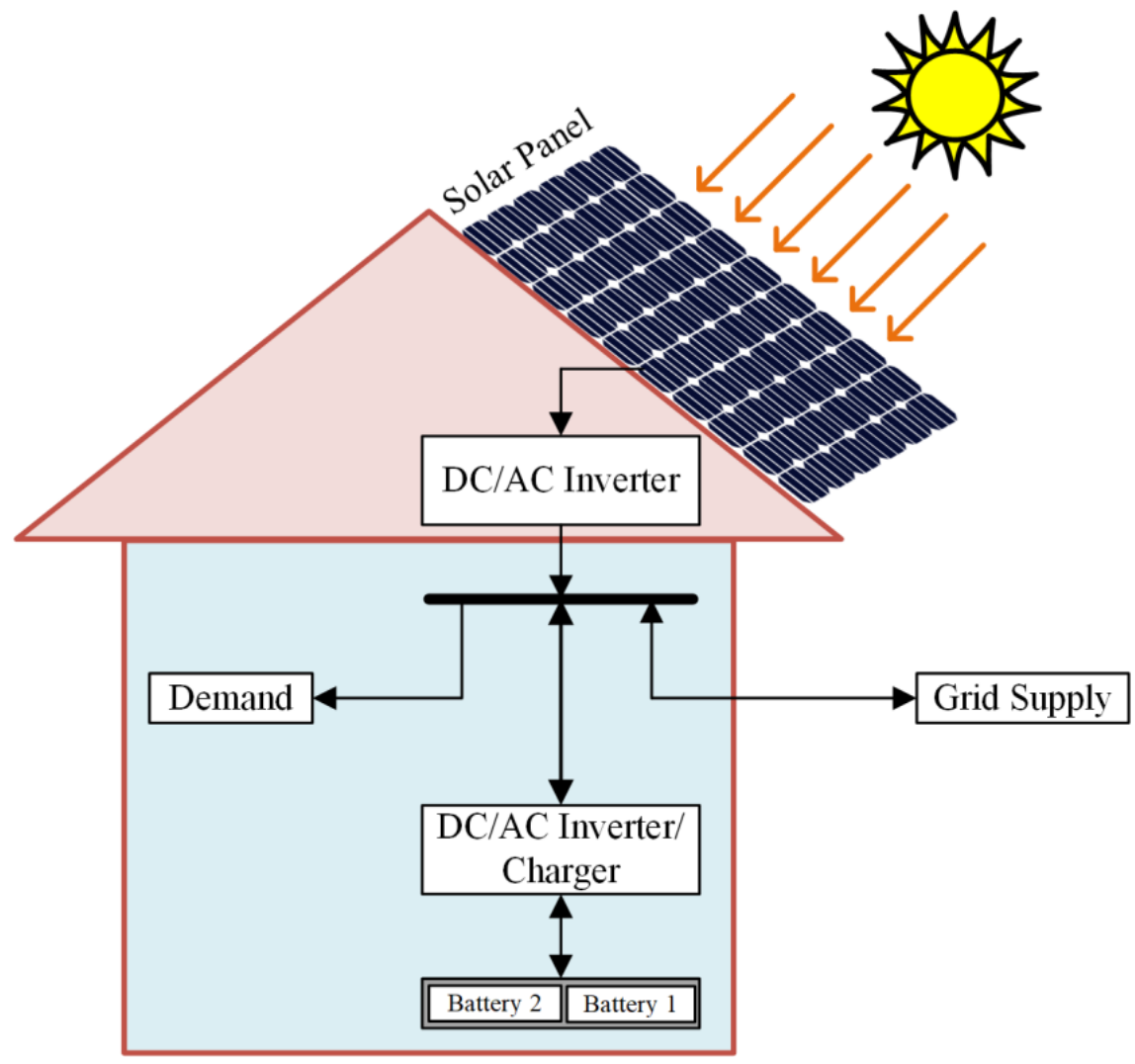

Figure 3. Schematic of the photovoltaic and battery storage systems (BESS).

Figure 4 shows the implementation of two batteries with a PV system and a utility grid. In this system, different tariff schemes were implemented to generate electricity from the PV panels, to store the excess power in the batteries, and to meet the unmet demand, which is provided by the grid, where $C_{g}$ is the generation tariff in $£ / \mathrm{kWh} ; C_{\mathrm{s} 1}$ is the rate in $£ / \mathrm{kWh}$ at which storage, $S_{1}$, is charged; $C_{\mathrm{s} 2}$ is the rate in $£ / \mathrm{kWh}$ at which storage, $S_{2}$, is charged; $C_{\mathrm{r} 1}$ is the retail tariff in $£ / \mathrm{kWh}$ met by the storage, $S_{1} ; C_{r 2}$ is the retail tariff in $£ / k W h$ met by the storage, $S_{2} ; C_{\text {gr }}$ is the tariff in $£ / k W h$ at which power is imported from the grid to meet the demand, and $C_{e}$ is the tariff at which power is exported to the grid.

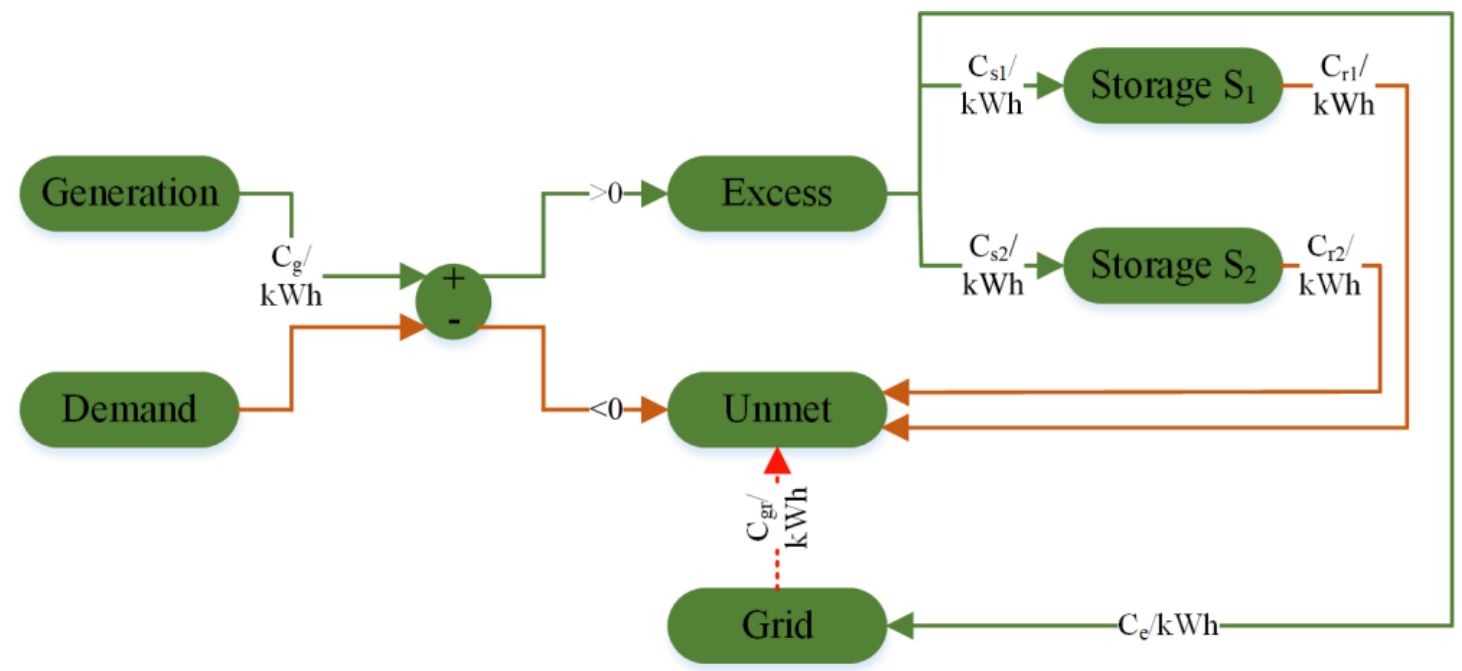

Figure 4. Implementation of two batteries with the PV system and utility grid. 


\subsection{Tariff Details}

\subsubsection{The Time-Of-Use Tariff}

The time-of-use (TOU) tariff is an alternative way to tackle the energy storage (ES) problem and provides opportunities for ES advancement. In the TOU tariff, there is a hike in the electricity cost during peak hours but a lower cost during non-peak hours. By taking up the TOU tariff, consumers can curtail inflated peak hours and switch to electricity during non-peak hours to reduce the energy crisis. With the closure of coal power plants, reducing the country's carbon footprint has a great impact on the amounts of energy that the UK can generate. Envisaging the energy shortages in the years to come, the TOU tariff can play a key role in mitigating the demand and reducing the pressure on the UK energy infrastructure [57].

A case study on the TOU tariff has been done in some European countries, and in some states of the USA, such as the Gulf Power Select Program (GPSP), showing a 41\% fall-off in electricity usage during peak hours [58]. According to the Statewide Pricing Pilot (SPP) examined in California [59], there is a decrease in the energy from $7.6 \%$ to $27 \%$ during peak hours by implementing the TOU tariff. In Norway, there was an $8-9 \%$ decrease in electricity use during the peak period by applying the TOU tariff.

\subsubsection{Export Tariff}

The export tariff allocates a revealed wage for every kilowatt-hour ( $\mathrm{kWh}$ ) of electricity exported, which is assigned by the authority. The generators in this system have a contract for the said period. This is beneficial to the consumers linked to this system for exporting the excess power to the utility grid. In this paper, the export tariff was fixed to $0.0464 £ / \mathrm{kWh}$.

\subsubsection{Import Tariff}

Power is imported from the grid when there is lack of solar PV generation to meet the unmet demand. Electricity is imported from the grid at the prescribed rates. The half-hourly electricity readings were collected for the entire year from the ELEXON portal [2]. The solar insolation data was gathered from the Sheffield solar microgeneration database [60]. In this model, the Economy 7 tariff [61], was used as the time-of-use tariff, having a peak time period of $7 \mathrm{~h}$ commencing from 7:00 to 22:00, is levied at $0.15 .8 \mathrm{E} / \mathrm{kWh}$, and the remaining time constituting the off-peak hours is charged at $0.06 £ / \mathrm{kWh}$, as shown in Figure 5.

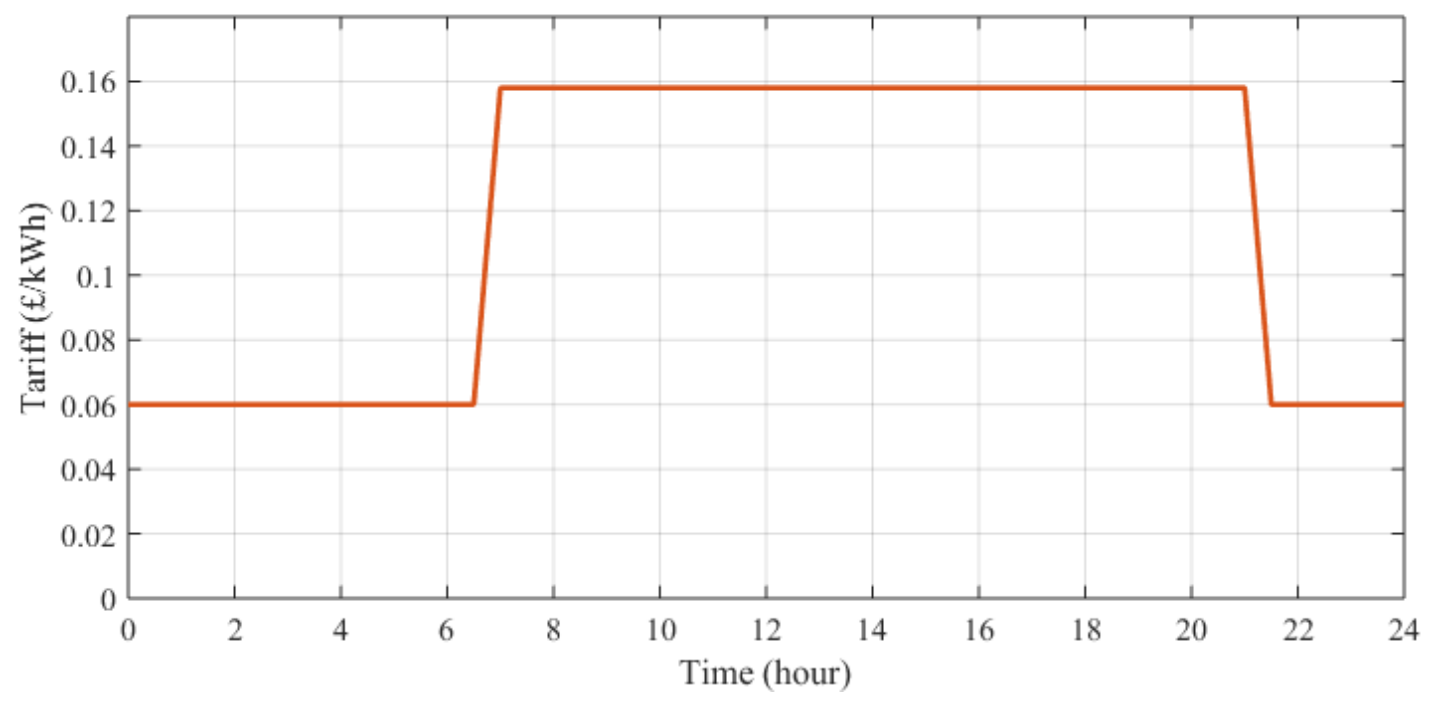

Figure 5. Economy 7 tariff. 


\section{Results and Discussion}

With the increase in technological development energy needs, and to overcome the concerns of global warming, researchers have begun to consider changing from limited and hazardous energy sources to environmentally compatible energy sources, such as solar PV.

Figure 1 shows the solar PV generation and the demand profile of the consumers, for the various days of the different months. During the period of low PV, the purchase of power from the grid is required to meet the consumer demand. When the intensity of the solar irradiance is high, and the consumer demand is low, the power needed for the onsite demand is evaluated, and the remaining power is sold to the grid. There is significantly higher electricity generation in the summer, as shown in the lower middle and right plots in Figure 1. The lower value of onsite demand allows us to charge the batteries according to the proposed methodology, and to export the remaining power at the prescribed export rate of $0.06 £ / \mathrm{kWh}$. On the contrary, there is notably low PV generation and increased consumer demand during the winters as shown in the upper left and middle plots in Figure 1. When the onsite consumer demand is greater than the PV generation, the batteries are utilized to supply power. The import of power from the grid is evaluated if the charge in the batteries to meet the demand reaches a minimum threshold level. Figure 2 shows the selection of the batteries for charging the first one on one day, and discharging the other for the other day. On the next day, the process is swapped by discharging the first one and charging the other, and this process works in a loop. Figure 4 reveals the pictorial view of our mathematical process, with a different rate for the generation, storage, export, and import of power.

The demonstration of three cases has been studied as:

\subsection{Case 1}

In this case, there is no solar PV or battery storage system feeding the consumer demand during the peak or non-peak hours. The demand is solely provided by the utility grid with the Economy 7 tariff applied. The power utilized to meet the demand is purchased at the rate of $0.06 £ / \mathrm{kWh}$ during the off-peak and at the rate of $0.158 £ / \mathrm{kWh}$ during peak hours. Figure 6 shows the grid-purchased electricity for the whole year, and recorded the highest demand of $19.8 \mathrm{~kW}$ in the month of January. Table 1 lists the cost of the electricity bought from the utility grid to meet the demand.

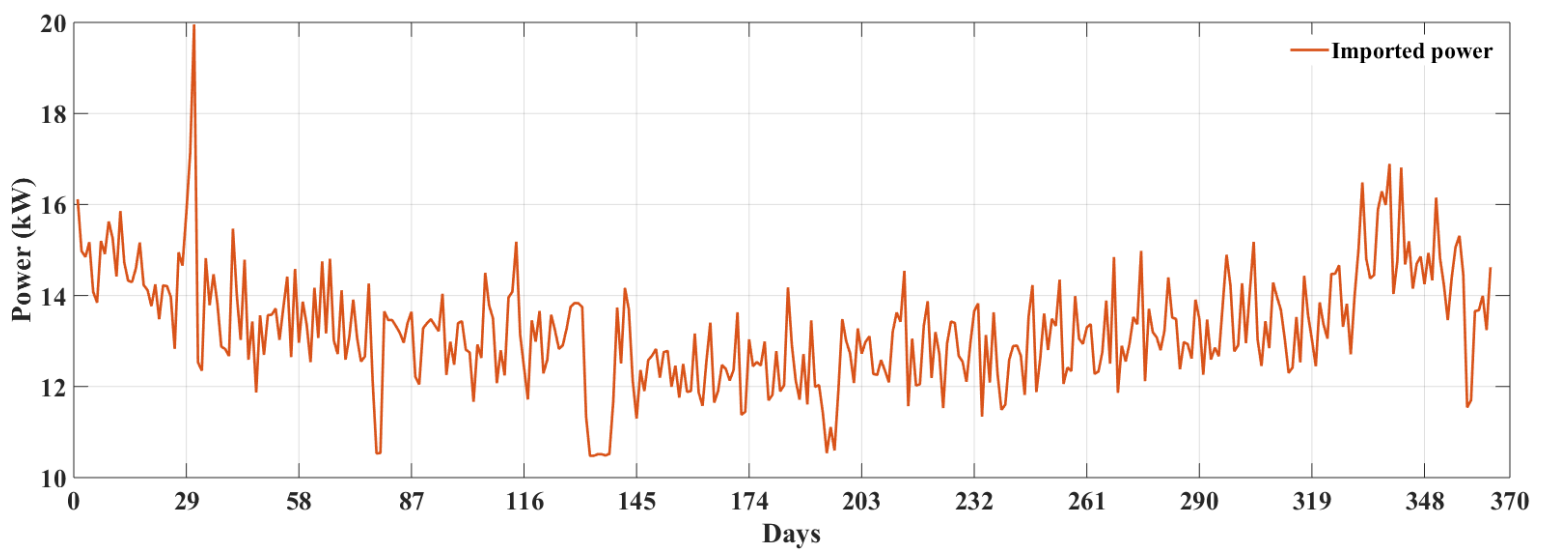

Figure 6. Power utilized without PV and battery system.

\subsection{Case 2}

In this case, there is no battery storage, and the load is connected with the solar PV system and the utility grid directly. The load demand of the system is met by the PV system first. If the PV cannot meet the total load demand, then the remaining energy is imported from the grid at the Economy 7 tariff. When the PV system output is more than load demand, the remaining PV energy is exported to 
the grid at the prescribed export tariff of $0.04 £ / \mathrm{kWh}$. Figure 7 shows the import and export profile for the entire year. Table 1 sums up the imported, exported, and net cost for this particular case.

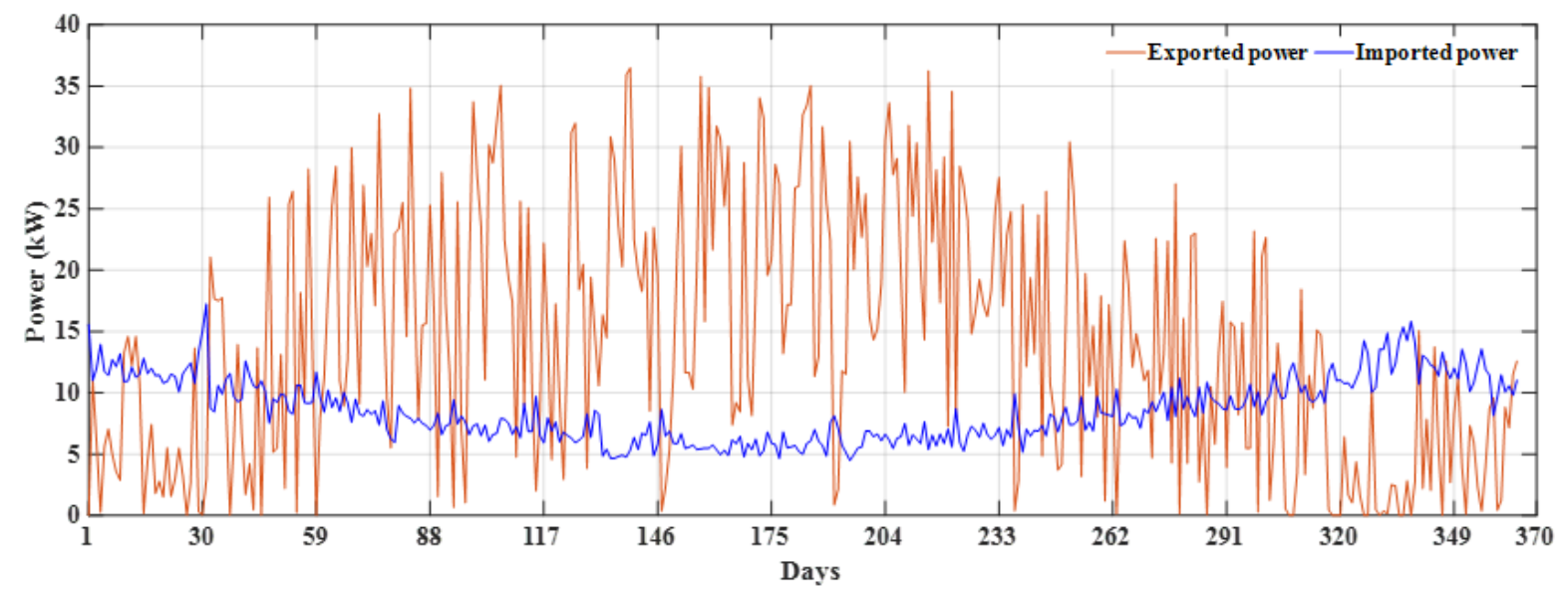

Figure 7. Import and export of the power profile with solar PV and no battery.

\subsection{Case 3}

In this case, the proposed hybrid PV and battery storage system is utilized. The batteries are charged and discharged according to the proposed methodology discussed above. Figure 8 shows the SOC of both batteries for the whole year. when the battery SOC reaches $100 \%$, i.e., from day 55 to day 301, the power is exported to the grid at prescribed export tariff, and if the SOC of the battery decreases to its minimal level, i.e., from day 9 to day 46 and from day 314 to day 365, the power is imported from the grid at the Economy 7 tariff. The battery discharge pattern is proposed in such a way that minimum power is imported during peak hours, which will decrease the cost of the electricity purchased. Table 1 shows the import, export, and net cost for the proposed methodology.

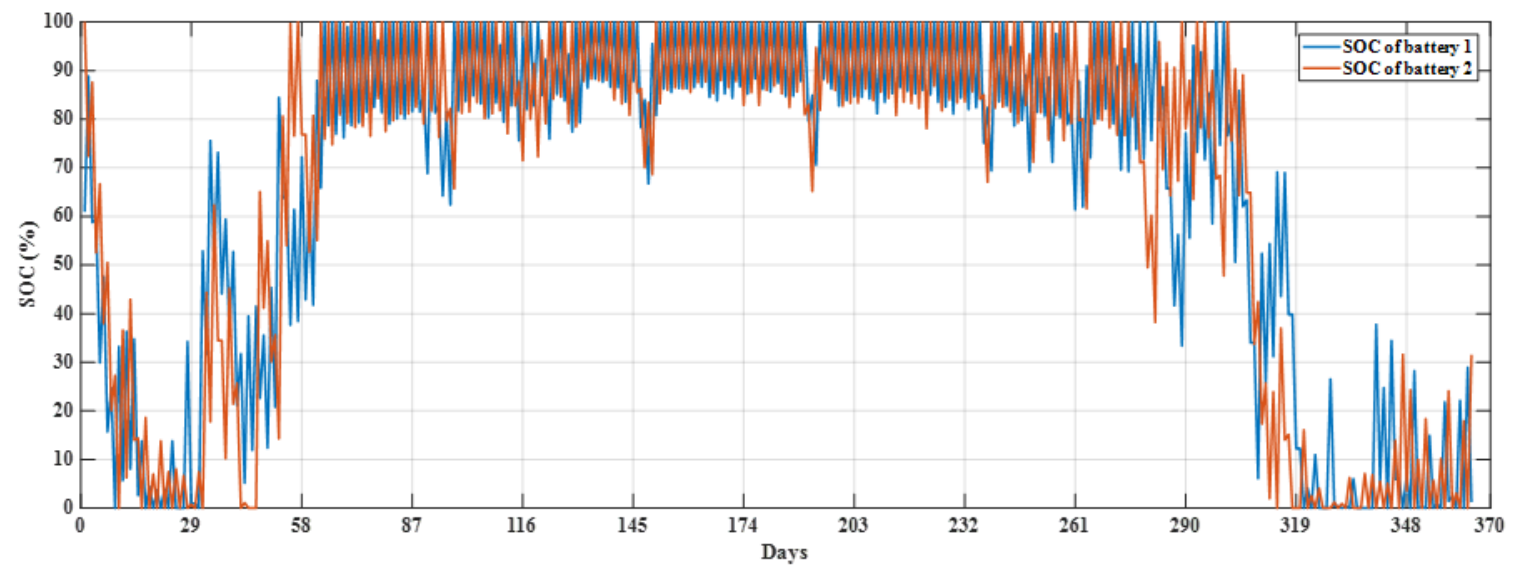

Figure 8. State of charge of the two batteries.

Table 1. Results of Cases 1, 2, and 3.

\begin{tabular}{|c|c|c|c|c|c|c|}
\hline Case & $\begin{array}{c}\text { PV } \\
\text { Installed }\end{array}$ & $\begin{array}{c}\text { Battery } \\
\text { Installed }\end{array}$ & $\begin{array}{c}\text { Economy } 7 \\
\text { Tariff } \\
\text { Applied }\end{array}$ & $\begin{array}{l}\text { Cost of Importing } \\
\text { Electricity }(£)(A)\end{array}$ & $\begin{array}{l}\text { Cost of Exporting } \\
\text { Electricity }(£)(B)\end{array}$ & $\begin{array}{c}\text { Net Value }(£) \\
(C=A-B)\end{array}$ \\
\hline 1 & No & No & Yes & 382.244 & Nil & 384.244 \\
\hline 2 & Yes & No & Yes & 164.218 & 102.520 & 61.698 \\
\hline 3 & Yes & Yes & Yes & 24.086 & 64.781 & -40.695 \\
\hline
\end{tabular}


The table shows the cost analysis of three cases. In Case 1, when no battery or PV was installed, the total cost of purchasing electricity was $384.244 £$. In Case 2, when the PV was installed, the cost of buying the electricity was $164.218 £$ and the cost of selling the extra power was $102.520 £$. In Case 3, when both PV and batteries were employed, the cost of electricity purchase was $24.086 £$ and the cost of selling the extra power was $64.781 £$. The net value in Case 3 was $-40.695 £$; the negative sign indicated that the amount earned from the exported tariff was greater than the cost of the electricity imported.

The statistical analysis of the scheme was examined for buying, selling or reserving the power for 365 days. It is worthwhile to mention that some statistical parameters were added to analyze this study and its benefits in detail. A very interesting study by Malvoni et al. [62], discussed the forecasting of PV power generation using weather input data techniques. Since the sporadic nature of weather conditions has a great impact on the PV system and their forecast, therefore, skewness and kurtosis would be important parameters that could define the probability distribution related to the import, export, and storage of power. The bigger values of kurtosis represent the narrow probability distribution and the smaller value correspond to a relatively flat distribution, and thus, a large number of small forecast errors [62]. The skewness indicated that the forecasting of the model was over/under-forecast. The negative skewness represented the right-skewed distribution and the under-forecast model. On the contrary, positive skewness showed the left-skewed distribution and the over-forecast model. The skewness value near zero indicated the symmetric distribution. Table 2 shows the values of these statistical parameters, as described in [62] for all the three cases. The values of the statistical parameters shown in Table 2 depict that the skewness was negative for all the three cases. In Case 1 , all of the electricity is fulfilled by the grid. In the early hours, the demand is relatively low, and as the day passes, the demand starts to increase. Therefore, the probability distribution is right-skewed with negative skewness. In Case 2, the initial demand is provided by the grid, but, as the day passes on, the solar PV system supports/shares the power demand generating the negative skewness for the import. But during midday, most of the demand is met by the solar PV system, and excess is transferred to the grid resulting in the delayed probability distribution. During the peak hours, the export is less right-skewed than the import. In Case 3, the load demand is initially less, and energy is stored in the battery system for the peak hours. This is in keeping with the fact that during initial hours, the battery is fully charged based upon the previous day's storage. Therefore, the energy is exported initially, resulting in a lesser right-skewed probability distribution of export than the import and the storage. Similarly, most of the demand in the early hours is fulfilled through the energy storage system. Thus, the current-day storage slowly increases as per the available energy of the solar PV system, resulting in the right-skewed probability distribution. Finally, as the most of the demand is met by the energy storage system, the import of power is required in the later hours of the day, resulting in a more right-skewed probability distribution of import. Therefore, the skewness, in this case, is minimum. Kurtosis in Case 1 shows that most of the demand is provided by the grid, which is comparatively less than Case 2, as in Case 2, some of the demand is shared by the solar PV system. In Case 3, the import is less, and low kurtosis shows the relatively flat probability distribution. Similarly, the kurtosis of the storage is high because the solar energy is low in the early daytime, at peak during midday, and reduces again during the later hours, generating a narrow probability distribution with a high kurtosis value. During the early hours, most of the energy (available) is used to increase the storage, and the remaining is exported to the grid. Similarly, the import of energy is required only in the case of low storage resulting in the relatively flat probability distribution of export and import.

Table 2. Statistical parameters of Cases 1,2, and 3.

\begin{tabular}{ccccccc}
\hline \multirow{2}{*}{ Case } & \multicolumn{3}{c}{ Skewness } & \multicolumn{3}{c}{ Kurtosis } \\
\cline { 2 - 7 } & Import & Export & Storage & Import & Export & Storage \\
\hline 1 & -0.1 & NA & NA & 3.8 & NA & NA \\
2 & -0.3 & -0.1 & NA & 5 & 4.2 & NA \\
3 & -1.6 & -0.3 & -0.4 & 6.3 & 7.3 & 7.6 \\
\hline
\end{tabular}


It is pertinent to mention that one of the important issue that could rise while implementing the approach is the capital cost. As we have proposed a dual battery system, it will burden a certain increase in the one-time capital cost, but is fruitful as the uninterrupted supply is provided at the low cost in addition to net profit and contrast with the conventional approaches.

\section{Conclusions}

Solar energy is considered to be an entirely clean and favorable technology that can be used as an autonomous power source for various off-grid applications, to mitigate the energy crisis. In this work, an optimization model for the hybrid dual battery storage system with solar PV was presented. The proposed system operated optimally by charging the one battery and discharging the other, and a mathematical cost function of the system was devised. Real data of the irradiance and load profile was collected from the consumers, and the influence of the two storage systems on the demand was evaluated. The proposed algorithm allowed the maximum usage of battery power during the peak hours and examined the cost analysis of all the three cases. The proposed dual battery with the solar PV system resulted not only in an uninterrupted supply, but also resulted in a good profit margin. The consequences of the comprehensive analysis of the proposed scheme over the conventional schemes, i.e., without the use of PV or the storage system, resulted in net savings, in addition to satisfying energy demands. The statistical analysis of import and export of power, and the energy storage presented in this study, favor the proposed methodology.

Author Contributions: Conceptualization, S.H.N., M.A.K., M.U.A. and H.J.K.; Data curation, S.H.N. and M.-S.K.; Investigation, S.H.N. and D.-H.K.; Methodology, S.H.N., M.A.K. and M.U.A.; Software, M.A.K., M.U.A. and M.-S.K.; Supervision, H.J.K.; Visualization, D.-H.K.; Writing—original draft, S.H.N.; Writing—review \& editing, S.H.N. and A.H.

Funding: This research received internal funding from 2-year Research Grant of Pusan National University.

Acknowledgments: This work was supported by a 2-Year Research Grant of Pusan National University.

Conflicts of Interest: The authors declare no conflict of interest.

\section{References}

1. Mobil, E. The Outlook for Energy: A View to 2040. Exxon Mobil 2013, 6. Available online: https:/ /cdn.exxonmobil.com/ / media/global/files/outlook-for-energy/2018/2018-outlook-forenergy.pdf (accessed on 4 April 2018).

2. Alexander, L.V.; Allen, S.K.; Bindoff, N.L.; Breon, F.-M.; Church, J.A.; Cubasch, U.; Emori, S.; Forster, P.; Friedlingstein, P.; Gillett, N. Summary for Policymakers. In Climate Change 2013: The Physical Science Basis. Contribution of Working Group I to the Fifth Assessment Report of the Intergovernmental Panel on Climate Change; Cambridge University Press: Cambridge, UK, 2013; pp. 3-30.

3. Houghton, D. Global Warming: The Complete Briefing; Cambridge University Press: Cambridge, UK, 1997; pp. 107-140.

4. Meadows, D.; Randers, J.; Behrens, W. The Limits to Growth: A Report for the Club of Rome's Project on the Predicament of Mankind; Universe Book: New York, NY, USA, 1972; Available online: https:/ / en.wikipedia. org/wiki/The_Limits_to_Growth (accessed on 4 April 2018).

5. Peet, J. Energy and the Ecological Economics of Sustainability; Island Press: Washington, WA, USA, 1992; pp. 114-123.

6. Minger, T.J. Greenhouse/Glasnost: the Sundance Symposium on Global Climate Change. In Greenhouse Glasnost: The Crisis of Global Warming: Essays; Ecco Press: Manhattan, NY, USA, 1990; pp. 101-109.

7. Haines, A.; McMichael, A.J.; Epstein, P.R. Environment and health: 2. Global climate change and health. Can. Med. Assoc. J. 2000, 163, 729-734.

8. Philipps, S.; Ise, F.; Warmuth, W. Fraunhofer ISE: Photovoltaics Report. 2017. Available online: http:/ / www.solarbabax.com/lib/lib019-pv-report2017.pdf (accessed on 4 April 2018).

9. Panagea, I.S.; Tsanis, I.K.; Koutroulis, A.G.; Grillakis, M.G. Climate change impact on photovoltaic energy output: The case of greece. Adv. Meteorol. 2014, 2014. [CrossRef] 
10. Sawin, J. Renewable Energy Policy Network for the 21st Century Renewables 2017 Global Status Report; REN21 Secretariat: Paris, France, 2017; pp. 1-302.

11. Renewable's 2018 Global Status Report. Available online: http://www.ren21.net/wp-content/uploads / 2018/06/17-8652_GSR2018_FullReport_web_-1.pdf (accessed on 4 April 2018).

12. Turner, J.A. A realizable renewable energy future. Science 1999, 285, 687-689. [CrossRef] [PubMed]

13. Rose, A. A global view of solar energy in rational units. Phys. Status solidi A 1979, 56, 11-26. [CrossRef]

14. Shah, A.; Torres, P.; Tscharner, R.; Wyrsch, N.; Keppner, H. Photovoltaic technology: The case for thin-film solar cells. Science 1999, 285, 692-698. [CrossRef] [PubMed]

15. Pacca, S.A. Global Warming Effect Appliedd to Electricity Generation Technologies; University of California: Berkeley, CA, USA, 2003; Available online: http:/ / rael.berkeley.edu/old_drupal/sites/default/files/oldsite-files/diss/Sergio_Pacca_2003.pdf (accessed on 4 April 2018).

16. Sherwani, A.F.; Usmani, J.A. Life cycle assessment of solar pv based electricity generation systems: A review. Renew. Sust. Energy Rev. 2010, 14, 540-544. [CrossRef]

17. McEvoy, A.; Markvart, T.; Castañer, L.; Markvart, T.; Castaner, L. Practical Handbook of Photovoltaics: Fundamentals and Applications; Elsevier: New York, NY, USA, 2003; pp. 566-567.

18. Stoppato, A. Life cycle assessment of photovoltaic electricity generation. Energy 2008, 33, 224-232. [CrossRef]

19. Aulich, H.A.; Schulze, F.W. Crystalline silicon feedstock for solar cells. Prog. Photovoltaics Res. Appl. 2002, 10, 141-147. [CrossRef]

20. Phylipsen, G.J.M.; Alsema, E.A. Environmental Life-Cycle Assessment of Multicrystalline Silicon Solar Cell Modules (Report No. 95057); Technical report; Department of Science, Technology and Society, Utrecht University: Princetonplein, The Netherlands, 1995; pp. 35-38.

21. Pacca, S.; Sivaraman, D.; Keoleian, G.A. Parameters affecting the life cycle performance of pv technologies and systems. Energy Policy 2007, 35, 3316-3326. [CrossRef]

22. Zsiborács, H.; Bai, A.; Popp, J.; Gabnai, Z.; Pályi, B.; Farkas, I.; Hegedúsné Baranyai, N.; Veszelka, M.; Zentkó, L.; Pintér, G. Change of real and simulated energy production of certain photovoltaic technologies in relation to orientation, tilt angle and dual-axis sun-tracking. A case study in hungary. Sustainability 2018, 10. [CrossRef]

23. Fthenakis, V.; Kim, H.C. Photovoltaics: Life-cycle analyses. Sol. Energy 2011, 85, 1609-1628. [CrossRef]

24. Linssen, J.; Stenzel, P.; Fleer, J. Techno-economic analysis of photovoltaic battery systems and the influence of different consumer load profiles. Appl. Energy 2017, 185, 2019-2025. [CrossRef]

25. Pintér, G.; Baranyai, N.H.; Wiliams, A.; Zsiborács, H. Study of photovoltaics and led energy efficiency: Case study in hungary. Energies 2018, 11, 790. [CrossRef]

26. Denholm, P.; Margolis, R.M. Evaluating the limits of solar photovoltaics (pv) in electric power systems utilizing energy storage and other enabling technologies. Energy Policy 2007, 35, 4424-4433. [CrossRef]

27. Perrin, M.; Saint-Drenan, Y.; Mattera, F.; Malbranche, P. Lead-acid batteries in stationary applications: Competitors and new markets for large penetration of renewable energies. J. Power Sources 2005, 144, 402-410. [CrossRef]

28. Zsiborács, H.; Baranyai, N.H.; Vincze, A.; Háber, I.; Pintér, G. Economic and technical aspects of flexible storage photovoltaic systems in europe. Energies 2018, 11. [CrossRef]

29. Nizetic, S.; Coko, D.; Marasovic, I. Experimental study on a hybrid energy system with small-and medium-scale applications for mild climates. Energy 2014, 75, 379-389. [CrossRef]

30. Vavilapalli, S.; Padmanaban, S.; Subramaniam, U.; Mihet-Popa, L. Power balancing control for grid energy storage system in photovoltaic applications-Real time digital simulation implementation. Energies 2017, 10, 928. [CrossRef]

31. Swaminathan, G.; Ramesh, V.; Umashankar, S.; Sanjeevikumar, P. Investigations of microgrid stability and optimum power sharing using robust control of grid tie pv inverter. In Advances in Smart Grid and Renewable Energy; Springer: Berlin, Germany, 2018; pp. 379-387.

32. Tamvada, K.; Umashankar, S.; Sanjeevikumar, P. Impact of power quality disturbances on grid-connected double fed induction generator. In Advances in Smart Grid and Renewable Energy; Springer: Berlin, Germany, 2018; pp. 339-345.

33. Castillo, A.; Gayme, D.F. Grid-scale energy storage applications in renewable energy integration: A survey. Energy Convers. Manag. 2014, 87, 885-894. [CrossRef] 
34. Leadbetter, J.; Swan, L.G. Selection of battery technology to support grid-integrated renewable electricity. J. Power Sources 2012, 216, 376-386. [CrossRef]

35. Wu, Z.; Tazvinga, H.; Xia, X. Demand side management of photovoltaic-battery hybrid system. Appl. Energy 2015, 148, 294-304. [CrossRef]

36. Mariaud, A.; Acha, S.; Ekins-Daukes, N.; Shah, N.; Markides, C.N. Integrated optimisation of photovoltaic and battery storage systems for uk commercial buildings. Appl. Energy 2017, 199, 466-478. [CrossRef]

37. Khalilpour, R.; Vassallo, A. Planning and operation scheduling of pv-battery systems: A novel methodology. Renew. Sust. Energy Rev. 2016, 53, 194-208. [CrossRef]

38. Pazouki, S.; Haghifam, M.-R. Optimal planning and scheduling of energy hub in presence of wind, storage and demand response under uncertainty. Int. J. Electr. Power 2016, 80, 219-239. [CrossRef]

39. Bortolini, M.; Gamberi, M.; Graziani, A. Technical and economic design of photovoltaic and battery energy storage system. Energy Convers. Manag. 2014, 86, 81-92. [CrossRef]

40. Tazvinga, H.; Zhu, B.; Xia, X. Optimal power flow management for distributed energy resources with batteries. Energy Convers. Manag. 2015, 102, 104-110. [CrossRef]

41. Pamparana, G.; Kracht, W.; Haas, J.; Díaz-Ferrán, G.; Palma-Behnke, R.; Román, R. Integrating photovoltaic solar energy and a battery energy storage system to operate a semi-autogenous grinding mill. J. Clean. Prod. 2017, 165, 273-280. [CrossRef]

42. Luo, F.; Meng, K.; Dong, Z.Y.; Zheng, Y.; Chen, Y.; Wong, K.P. Coordinated operational planning for wind farm with battery energy storage system. IEEE Trans. Sustain. Energy 2015, 6, 253-262. [CrossRef]

43. Zou, P.; Chen, Q.; Xia, Q.; He, G.; Kang, C. Evaluating the contribution of energy storages to support large-scale renewable generation in joint energy and ancillary service markets. IEEE Trans. Sustain. Energy 2016, 7, 808-818. [CrossRef]

44. Quoilin, S.; Kavvadias, K.; Mercier, A.; Pappone, I.; Zucker, A. Quantifying self-consumption linked to solar home battery systems: Statistical analysis and economic assessment. Appl. Energy 2016, 182, 58-67. [CrossRef]

45. Hoppmann, J.; Volland, J.; Schmidt, T.S.; Hoffmann, V.H. The economic viability of battery storage for residential solar photovoltaic systems-a review and a simulation model. Renew. Sustain. Energy Rev. 2014, 39, 1101-1118. [CrossRef]

46. Kairies, K.-P.; Magnor, D.; Sauer, D.U. Scientific measuring and evaluation program for photovoltaic battery systems (wmep pv-speicher). Energy Proc. 2015, 73, 200-207. [CrossRef]

47. Linden, D. Fuel and Energy. In Handbook of Batteries; McGraw-Hill: NYC, NY, USA, 1995; p. 265.

48. Luo, X.; Wang, J.; Dooner, M.; Clarke, J. Overview of current development in electrical energy storage technologies and the application potential in power system operation. Appl. Energy 2015, 137, 511-536. [CrossRef]

49. Ali, M.U.; Nengroo, S.H.; Khan, M.A.; Zeb, K.; Kamran, M.A.; Kim, H.-J. A real-time simulink interfaced fast-charging methodology of lithium-ion batteries under temperature feedback with fuzzy logic control. Energies 2018, 11. [CrossRef]

50. Menanteau, P.; Finon, D.; Lamy, M.-L. Prices versus quantities: Choosing policies for promoting the development of renewable energy. Energy Policy 2003, 31, 799-812. [CrossRef]

51. Fouquet, D.; Johansson, T.B. European renewable energy policy at crossroads-Focus on electricity support mechanisms. Energy Policy 2008, 36, 4079-4092. [CrossRef]

52. Mendonca, M. Feed-In tariffs: Accelerating the Deployment of Renewable Energy London; Cromwell Press: Trowbridge, UK, 2007; pp. 30-31.

53. Deploying Renewables: Principles for Effective Policies; Organisation for Economic Co-operation and Development (OECD)/International Energy Agency (IEA): Paris, France, 2008.

54. Deutsche Bank. Global Energy Transfer Feed-In Tariffs for Developing Countrie; DB Climate Change Advisers (DBCCA): Frankfurt, Germany, April 2010; Available online: http:/ /www.dbcca.com/dbcca/EN/_media/ GET_FiT_Program.pdf (accessed on 4 April 2018).

55. Rickerson, W.H.; Sawin, J.L.; Grace, R.C. If the shoe fits: Using feed-in tariffs to meet us renewable electricity targets. Electr. J. 2007, 20, 73-86. [CrossRef]

56. Cherrington, R.; Goodship, V.; Longfield, A.; Kirwan, K. The feed-in tariff in the uk: A case study focus on domestic photovoltaic systems. Renew. Energy 2013, 50, 421-426. [CrossRef] 
57. Yang, L.; Dong, C.; Wan, C.J.; Ng, C.T. Electricity time-of-use tariff with consumer behavior consideration. Int. J. Prod. Econ. 2013, 146, 402-410. [CrossRef]

58. Faruqui, A.; Sergici, S. Household response to dynamic pricing of electricity: A survey of 15 experiments. J. Regul. Econ. 2010, 38, 193-225. [CrossRef]

59. Faruqui, A.; George, S. Quantifying customer response to dynamic pricing. Electr. J. 2005, 18, 53-63. [CrossRef]

60. Sheffield Solar. Available online: http://www.solar.sheffield.ac.uk/S.S.n.d (accessed on 27 October 2015).

61. Newborough, M.; Augood, P. Demand-side management opportunities for the uk domestic sector. IEE Proc. Gener. Transm. Distrib. 1999, 146, 283-293. [CrossRef]

62. Malvoni, M.; De Giorgi, M.G.; Congedo, P.M. Forecasting of pv power generation using weather input data-preprocessing techniques. Energy Proced. 2017, 126, 651-658. [CrossRef]

(C) 2018 by the authors. Licensee MDPI, Basel, Switzerland. This article is an open access article distributed under the terms and conditions of the Creative Commons Attribution (CC BY) license (http://creativecommons.org/licenses/by/4.0/). 